\title{
Peningkatan Digitalisasi Pariwisata di Wilayah Desa Purwoharjo, Kulon Progo
}

\author{
Desideria Cempaka Wijaya Murti ${ }^{1}$, Zikrina Ratri Kusumastuti ${ }^{2}$, Victoria Sundari Handoko ${ }^{3}$, Antonius Bima Murti Wijaya ${ }^{4}$ \\ Universitas Atma Jaya Yogyakarta, Jl. Babarsari No.43, Janti, Caturtunggal, Kec. Depok, Kabupaten Sleman, Daerah Istimewa Yogyakarta \\ 55281 \\ Email: desideria.murti@uajy.ac.id ${ }^{1}$
}

Received: December 24, 2021 ; Revised: -; Accepted for Publication January 4, 2022; Published: January 4, 2022

\begin{abstract}
Abstrak - Purwoharjo merupakan suatu kawasan desa yang terletak di daerah Pegunungan Menoreh, Kulon Progo, Yogyakarta. Situasi pandemic COVID-19 membawa dampak bagi keberlanjutan pariwisata di kawasan Desa Purwoharjo. Penurunan jumlah pengunjung dalam dua tahun masa pandemic akibat dari kebijakan PKKM dan PSBB mendorong Wisata Desa Purwoharjo untuk beradaptasi. Pandemi merupakan suatu permasalahan fenomena alam yang perlu dihadapi dengan pendekatan yang adaptif antara manusia dan alam. Melalui empat komponen dalam pendekatan human and ecological well-being, digitalisasi dipilih sebagai langkah alternatif inovasi dari permaslaahan yang ada. Yang mana digitalisasi ini dapat bermanfaat bagi upaya peningkatan nilai produk wisata Desa Purwoharjo dan mempertahankan pariwisata setempat sebagai ecosystem service. Pada proses ini berupaya menggabungkan ide dan pemikiran dari masyarakat pengelola wisata dan kelompok diluar pengelola untuk menciptakan inovasi serta meningkatkan nilai produk wisata setempat. Dengan metode Community-based Tourism (CBT) yang diguakan melibatkan kelompok pengelola desa wisata secara aktif dan juga kelompok lain sebagai fasilitator diharapkan dapat memberikan wawasan dan berinovasi bersama untuk pengembangan desa wisata Purwoharjo. Dengan proses fasilitator pelatihan digitalisasi dengan kelompokkelompok di luar pengelola wisata.
\end{abstract}

Kata Kunci- Digitalisasi, Pariwisata, Community-based Tourism

\section{PENDAHULUAN}

Pandemi COVID-19 membawa banyak dampak bagi berbagai sector termasuk sector pariwisata. Adanya kebijakan dimulai dari Pembatasan Sosial Berskala Besar (PSBB) sampai dengan Pemberlakuan Pembatasan Kegiatan Masyarakat (PPKM), yang diberlakukan selama pandemic, berdampak besar bagi sector pariwisata yang mengalami penurunan kunjungan wisata. Adanya kebijakan tersebut membawa dampak kendala dalam bentuk promosi wisata pada pendatang yang sering kali kunjungan di tempat wisata tersebut. Hal ini mendorong perlunya adaptasi dalam upaya promosi serta meningkatkan nilai produk wisata dan menciptakan lingkup wisata yang aman selama masa pandemic COVID-19. Salah satunya dengan cara digitalisasi sector pariwisata.

Upaya adaptif yang dilakukan mengarah pada human and ecological well-being, tidak hanya membentuk suatu hubungan kepada alam saja namun perlu adanya pembangunan relasi adaptif yang baik antara manusia dan alam [1]. Manusia dan alam akan saling berdampak satu sama lain dalam arti manusia akan memberikan dampak pada alam dan alam juga akan memberikan dampak sebagai reksi atas apa yang manusia (individua atau masyarakat) lakukan. Dalam hal ini perlu adanya keterkaitan antara ecosystem service tidak lagi bercentral pada anthropocentric namun juga bagaimana timbal balik manusia memberikan dampak bagi alam [2].

Pada studi kasus pengembangan pariwisata di daerah Magelang basis pengembangan kelompok pengelola pariwisata(Community-based Tourism) ini mengembangkan digitalisasi manajemen pengelolaan wisatawan [3]. Permasalahan dalam kajian ini dimana waktu kunjungan yang pendek sehingga banyak lokasi wisata yang belum dapat dikunjungi oleh wisatawan. Untuk menangani permasalahan ini terdapat bentuk staragi promosi digital melalui media sosial yang digunakan. Keberhasilan startegi yang mereka lakukan yaitu dengan terbuktinya tranding topic pada platform media sosial yang digunakan.

Berbeda dengan permasalahan yang ditemukan pada studi kasus digitalisasi desa dan pembangunan potensi wisata di Desa Kerta, Kabupaten Gianyar, Bali [4]. Terdapat beberapa permasalahan yang mendasar dimana terdapat potensi wisata namun masih terdapat kendala dalam pengelolaannya termasuk pada pembentukan kelompok Pokdarwis yang kurang partisipatif. Selain itu wisata juga kurang dikelola dan dipromosikan dengan baik. Dalam hal ini kegiatan pelatihan pemberdayaan komunitas dalam pengunaan Aplikasi AR Desa Kerta, sosialisasi website Desa Kerta, dan pelatihan SEO dan Google My Bussiness.

Desa Purwoharjo yang terletak di Pegunungan Menoreh, Kulon Progo yang merupakan kawasan wisata juga merasakan dampak selama masa pandemic COVID- 19, yang mana terjadi penurunan kunjungan wisata dari rata- rata 11.000 pengunjung pada tahun 2017- 2018 menjadi 2.000 pengunjung pada tahun 2020-2021(data kunjungan wisata Desa Purwoharjo). Potensi letak geografis yang masih dikelilingi dengan perbukitan dan wisata alam yang ada menjadi ecosystem service yang dapat ditingkatkan nilai produknya oleh masyarakat setempat. Di Desa Purwoharjo sendiri memiliki tiga bentuk destinasi wisata yang meliputi wisata edukasi(Desa Wisata Tinalah), wisata alam(Gua Sriti dan Puncak Kleco), dan wisata sejarah(Museum Sandi). Destinasi wisata alam terbuka yang berada di kawasan Desa Purwoharjo tersebut berpotensi dapat dijadikan alternatif kunjungan wisata berbagai kalangan. Dengan pengembangan digitalisasi pariwisata di kawasan Desa Purwoharjo.

Upaya peningkatan ecosystem service yang ada dapat bertujuan meningkatkan kesejahteraan masyarakat setempat. Dengan berbasis pada partisipasi dan pengembangan kelompok(Community-based Tourism), kelompok pengelola desa wisata dalam strategi ini berperan sebagai aktor utama yang merumuskan suatu permasalahan yang ada hingga pada penentuan keputusan yang diambil. Pendekatan atau startegi CBT yang berbasis kemasyarakatan ini diharapkan dapat menjadi bentuk strategi yang tepat 
digunakan dalam pengembangan pariwisata di Desa Purwoharjo.

\section{Metode PENGabdian}

Metode yang digunakan dalam pelaksanaan kegiatan ini yaitu merupakan bentuk kualitatif deskriptif. Kulitatif deskriptif merupakan merupakan suatu metode yang digunakan untuk mendeskripsikan atau menggambarkan secara sistematis, factual dan juga akurat berdasarkan fakta yang terjadi Kulaitatif deskriptif yang dimaksud mencoba mendeskripsikan pelaksanaan program peningkatan digitalisasi wisata di Desa Purwoharjo.

Terdapat dua bentuk dalam mendapatkan informasi tersebut yaitu bentuk Focus Group Discussion(FGD) dan wawancara peserta pelatihan yang mana merupakan anggota kelompok pengelola wisata Desa Purwoharjo. FGD dapat dilakukan melalui proses pelatihan selama 6 hari, 17 Desember - 22 Desember 2021. Sedangkan pada proses wawancara dilakukan pada setiap akhir sesi pelatihan yang dilaukan selama 6 hari tersebut.

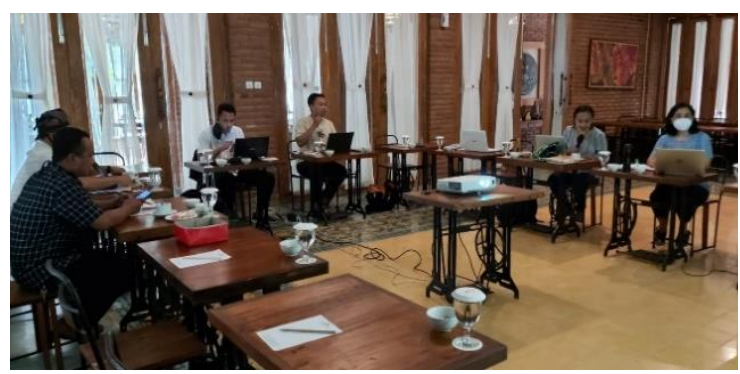

Gambar 1 Proses FGD

\section{Teori/ kerangka berpikir}

\section{Community-based Tourism (CBT)}

Community-based Tourism merupakan bagian dari metode pengembangan masyarakat yang berbasis pada kekuatan kelompok dalam mengelola suatu ecosystem service di wilayah kelompok tersebut berada [5]. Konsep pengembangan komunitas dengan Community-based Tourism tersebt bertujuan dalam upaya well-being dalam mempertahankan sustainable livelihood dan memepertahankan lokalitas sosial budaya serta lingkungan setempat. Terdapat siklus circular dimana riset dan aksi pemecahan masalah tidak akan berhenti pada suatu titik tujuan, namun terus terdapat feedback atau tindak lanjut kajian dari apa yang telah dilakukan guna pengembangan program. Strategi Community-based Tourism ini digunakan dalam pendekatan lanjutan dalam perancangan program pengembangan komunitas masyarakat pengelola wisata Desa Purwoharjo pada tahun 2019.

Terdapat prinsip yang perlu diperhatikan dalam pengunaan Community-based Tourism yaitu [5];
1. Melibatkan dan dorongan terhadap kelompok dalam ownership dan manajement yang transparan

2. Membangun bentuk kerjasama dengan pihak stakeholders yang relevan dengan kebutuhan pengembangan kelompok

3. Memngumpukan suatu pengakuan dengan autoritas yang relevan

4. Meningkatkan kesejahteraan dan memperbaiki martabat manusia

5. Transparansi dan keadilan dalam mekanisme pembagian

6. Meningkatkan jaringan ekonomi lokal dan regional

7. Menghormati budaya lokal dan tradisi setempat

8. Berkontribusi dalam konservasi sumber daya

9. Meningkatkan kualitas pengalaman pengunjung dengan cara memeperkuat peran interaksi pemandu dan pengunjung

10. Pengelolaan keuangan secara mandiri.

Terdapat bentuk awal pendekatan kepada kelompok masyarakat yang dimulai pada program Abdimas 2020 oleh Universitas Atma Jaya Yogyakarta. Pada program pengabdian tersebut telah menghasilkan bentuk branding wisata edukasi Dewi Tinalah. Dari tahapan pendekatan tersebut banyak menjadi dasar pengenalan terhadap kawasan Purwoharjo. Dari program yang telah dilakukan tersebut terdapat tindak lanjut dimana pembuatan aplikasi yang telah dirancang masih menjadi kendala dan belum beroprasi sesuai yang diharapkan, selain itu perlu adanya variansi strategi promosi produk wisata. Berhubungan dengan pandemic COVID-19 pengunjung dari wisata di Dewi Tinalah khusunya mengalami penurunan yang drastis. Pada bulan Maret 2020 bisa memperoleh pendapatan sampai dengan 100 juta lebih (wawancara pengelola pokdarwis Dewi Tinalah) kemudian karena pandemi COVID-19 kunjungan wisatawan bisa dikatakan tidak ada dan baru terdapat kunjungan wisatawan pada bulan Agustus 2020 meskipun tidak banyak jumlahnya.

Dalam tahapan selanjutnya terdapat bentuk diskusi dan upaya pemetaan. Dikusi ini meliputi feedback atau evaluasi program yang telah dikerjakan sebelumnya yang berkaitan Abdimas 2020 yaitu branding Dewi Tinalah. Dengan upaya memberluas cakupan dan tidak hanya kawasan wisata Tinalah, perlu adanya pemetaan yang baru. Pemetaan tersebut bertujuan sebagai landasan perencanaan program yang diupayakan oleh kelompok pengelola wisata maupun tim kerja sama pengabdian. Dari hal ini dapat dipetakan dimana terdapat tiga bentuk wisata di Desa Purwoharjo:

a. Kawasan wisata sejarah: Museum Sandi dan sekitarnya

b. Kawasan wisata alam: Gua Sriti dan Puncak Kleco

c. Kawasan wisata edukasi: Desa Wisata Tinalah 
Dari hasil pemetaan dan cakupan bentuk digitalisasi pariwisata yang telah dirancang selanjutnya dapat menentukan metode realisasi perencanaan yang tepat digunakna yaitu dengan mengadakan bentuk pelatihan dan fasilitator dari kelompok pendamping diluar kelompok selama 5 hari, 17 Desember - 22 Desember 2021.

\section{Digitalisasi}

Digitalisasi pada awalnya merupakan bentuk teknologi informasi, yang mana dapat diartikan adanya proses transformasi informasi dalam berbagai bentuk baik teks, foto, maupun video diubah dalam bentuk media digital. Digitalisasi sendiri merupakan suatu konsep yang kompeleks karena melibatkan beberapa langkah berbeda yang diterapkan pada setiap kelompok [6]. Adanya kemajuan teknologi informasi pada era saat ini mendorong semakin banayaknya inovasi- inovasi digitalisasi di berbagai sector terutama dalam pembangunan inovasi pengebangan bisnis.

Dalam bisnis inovasi pengembangan digitalisasi ini menjadi semakin maju pesat karena mengubah prespektiv relasi dengan konsumen [7]. Hal ini dapat dilihat dimana hubungan dengan konsumen bukan lagi dilihat sebagai suatu orientasi konsumsi produk semata namun hingga pada bagaimana tahapan service atau pelayanan terhadap konsumen. Terutama pada sector pariwisata yang memiliki bentuk produk pelayanan wisata.

Praktik digitalisasi yang dilakuakan dalam upaya peningkatan nilai produk wisata di kawasan Desa Purwoharjo yaitu:

1. Visualisasi obyek budaya dan alam melalui foto dan video dalam media multiplatform yang dapat meningkatkan pemasaran destinasi

2. Integrasi pembayaran melalui Cashless atau QRIS (Quick Response Code Indonesian Standard)

3. Penggunaan aplikasi mobile desa yang mendukung paket wisata, guide lokal, serta mempermudah wisatawan bertamasya dengan adanya sarana pendukung wisata berbasis mobile phone seperti charging station.

Untuk mencapai target upaya digitalisasi tersebut maka terdapat beberapa pengadaan pelatihan yang secara aktif melibatkan masyarakat/ kelompok pengelola lokasi kegaitan wisata Desa Purwoharjo.

\section{HASIL DAN PEMBAHAAN}

\section{Pelaksanaan}

Pelatihan yang dilakukan selama 6 hari, 17 Desember - 22 Desember 2021 di kawasan wisata alam Dewi Tinalah dihadiri oleh perwakilan- perwakilan pengelola wisata Desa Purwoharjo. Pelatihan upaya peningkatan digitalisasi ini merupakan hasill dari bentuk diskusi dan evaluasi dari program pengabdian yang dilakukan oleh Universitas Atma Jaya Yogyakarta pada 2019. Pada program sebelumnya terdapat pembentukan icon wisata alam Dewi Tinalah dan juga upaya branding produk wisata melalui website. Namun hal ini masih menjadi kendala dimana pelaksanaan web tersebut belum berjalan semestinya karena terdapat beberapa kendala kemampuan pengelolaan media promosi tersebut.

Melalui hasil evaluasi tersbut membawa pada upaya kegiatan lanjutan yang dirancang saat ini berupa pengabdian dalam upaya peningkatan digitalisasi wisata di Desa Purwoharjo. Bentuk evaluasi dan diskusi lanjutan bersama kelompok pengelola wisata tersebut menghasilkan pemetaan ruang lingkup digitalisasi yang lebih luas. Ruang lingkup pengembangan wisata dan digitalisasi yang digunakan dalam pengabdian saat ini diperluas dimana mencakup seluruh kawasan Desa Purwoharjo yang memiliki berbagai jenis model wisata, terdapat wisata alam, wisata edukasi, dan wisata sejarah. Selain pada cakupan wilayah, lingkup digitalisasi wisata yang digunakan juga menjadi luas dimana tidak hanya optimalisasi promosi melalui platform digital namun terdapat juga bentuk digitalisasi adaptif terhadap situasi pandemic yaitu integrasi QRIS(Quick Response Code Indonesian Standard) model transaksi digital. Dengan cakupan yang lebih luas pula ada upaya penggunaan aplikasi mobile desa yang mendukung paket wisata, guide lokal, serta mempermudah wisatawan bertamasya dengan adanya sarana pendukung wisata berbasis mobile phone seperti charging station. Terdapat pula lingkup upaya visualisasi obyek budaya dan alam melalui foto dan video dalam media multiplatform yang dapat meningkatkan pemasaran destinasi wisata.

Realisasi upaya peningkatan digitalisasi dalam lingkup yang telah diperbaharui tersebut berupa diadakannya pelatihan dengan materi- materi yang mendukung realisasi dari lingkup peningkatan digitalisasi tersebut. Terdapat pemetaan enam materi yang disajikan yaitu;

\section{Tabel 1 Pemetaan Materi Pelatihan}

\begin{tabular}{|l|c|c|c|}
\hline No & Kegiatan & $\begin{array}{c}\text { Outcome } \\
\text { Kegiatan }\end{array}$ & $\begin{array}{c}\text { Dampak Bagi } \\
\text { Masyarakat }\end{array}$ \\
\hline 1 & Fotografi: & Kelompok & Meningkatkan \\
& Pelatihan, & pengelola & kunjungan \\
& mentoring, dan & wisata mampu \\
pisata melalui \\
produksi foto \\
& & $\begin{array}{c}\text { memahami dan } \\
\text { mengetahui }\end{array}$ & eksistensi \\
& & pemasaran \\
& & teknik dasar & digital pada \\
& & fotografi. & media sosial. \\
& & Kelompok & Hal ini \\
& & pengelola juga & berdampak \\
& & dapat memiliki & pada \\
& & banyak & peningkatan \\
& & persediaan foto & wisatawan dan \\
& & yang dapat & juga \\
& & digunakan & peningkatan \\
& & sebagai media & ekonomi \\
& & promosi di & \\
& & \multicolumn{3}{|c}{} \\
\end{tabular}




\begin{tabular}{|c|c|c|c|}
\hline & & $\begin{array}{l}\text { platform media } \\
\text { sosial meliputi } \\
\text { wisata alam, } \\
\text { edukasi, dan } \\
\text { sejarah. }\end{array}$ & $\begin{array}{l}\text { masyarakat } \\
\text { setempat. }\end{array}$ \\
\hline 2 & $\begin{array}{l}\text { Videografi: } \\
\text { Pelatihan, } \\
\text { mentoring, } \\
\text { dan produksi } \\
\text { video }\end{array}$ & $\begin{array}{c}\text { Kelompok } \\
\text { pengelola } \\
\text { wisata mampu } \\
\text { memahami dan } \\
\text { mengetahui } \\
\text { teknik dasar } \\
\text { videografi. } \\
\text { Kelompok } \\
\text { pengelola juga } \\
\text { dapat memiliki } \\
\text { banyak } \\
\text { persediaan } \\
\text { video yang } \\
\text { dapat } \\
\text { digunakan } \\
\text { sebagai media } \\
\text { promosi di } \\
\text { platform media } \\
\text { sosial meliputi } \\
\text { wisata alam, } \\
\text { edukasi, dan } \\
\text { sejarah. } \\
\end{array}$ & $\begin{array}{l}\text { Meningkatkan } \\
\text { kunjungan } \\
\text { wisata melalui } \\
\text { eksistensi } \\
\text { pemasaran } \\
\text { digital pada } \\
\text { media sosial. } \\
\text { Hal ini } \\
\text { berdampak } \\
\text { pada } \\
\text { peningkatan } \\
\text { wisatawan dan } \\
\text { juga } \\
\text { peningkatan } \\
\text { ekonomi } \\
\text { masyarakat } \\
\text { setempat. }\end{array}$ \\
\hline 3 & $\begin{array}{c}\text { Public } \\
\text { Speaking \& } \\
\text { Story Telling: } \\
\text { Pelatihan dan } \\
\text { mentoring } \\
\text { untuk Tour } \\
\text { Guide }\end{array}$ & $\begin{array}{c}\text { Guide mampu } \\
\text { menceritakan } \\
\text { mengenai } \\
\text { destinasi } \\
\text { wisata } \\
\text { kawasan Desa } \\
\text { Purwoharjo } \\
\text { baik dari aspek } \\
\text { sejarah, alam, } \\
\text { dan edukasi } \\
\text { dengan baik } \\
\text { dan } \\
\text { tersetruktur. }\end{array}$ & $\begin{array}{c}\text { Meningkatkan } \\
\text { kemampuan } \\
\text { profesionalitas } \\
\text { kerja dari guide } \\
\text { wisata. } \\
\text { Berdampak } \\
\text { pada } \\
\text { peningkatan } \\
\text { ekonomi bagi } \\
\text { guide lokal di } \\
\text { kawasan Desa } \\
\text { Purwoharjo. }\end{array}$ \\
\hline 4 & $\begin{array}{l}\text { Optimalisasi } \\
\text { Pengunaan } \\
\text { Aplikasi } \\
\text { "Mbak Dewi": } \\
\text { Pelatihan dan } \\
\text { mentoring }\end{array}$ & $\begin{array}{c}\text { Tour guide } \\
\text { mampu } \\
\text { mengunakan } \\
\text { dan memahami } \\
\text { cara dari } \\
\text { kegunaan } \\
\text { Aplikasi } \\
\text { "Mbak Dewi" } \\
\text { untuk wilayah } \\
\text { wisata di Desa } \\
\text { Purwoharjo. }\end{array}$ & $\begin{array}{l}\text { Meningkatkan } \\
\text { ekonomi } \\
\text { dengan } \\
\text { pemahaman } \\
\text { dalam } \\
\text { penambahan } \\
\text { nilai paket } \\
\text { wisata berbasis } \\
\text { teknologi } \\
\text { digital. }\end{array}$ \\
\hline 5 & $\begin{array}{c}\text { Cashless } \\
\text { Society: } \\
\text { Pelatihan } \\
\text { pendaftaran } \\
\text { dan pengunaan } \\
\text { QRIS pada } \\
\text { pengelola } \\
\text { UMKM } \\
\end{array}$ & $\begin{array}{l}\text { UMKM dan } \\
\text { juga pemilik } \\
\text { homestay } \\
\text { dapat } \\
\text { memahami } \\
\text { keuntungan } \\
\text { cashless dan } \\
\text { mengunakan }\end{array}$ & $\begin{array}{l}\text { Meningkatkan } \\
\text { perekonomian } \\
\text { masyarakat } \\
\text { dengan } \\
\text { meningkatkan } \\
\text { opsi atau } \\
\text { pilihan metode }\end{array}$ \\
\hline
\end{tabular}

\begin{tabular}{|l|c|c|c|}
\hline & platform & pembayaran \\
tersebut & cashless. \\
sebagai media & \\
transaksi & \\
digital. & \\
\hline
\end{tabular}

\section{Proses kegiatan pelatihan}

Pelatihan yang dilaksanakan sebagai upaya peningkatan digitalisasi ini meliputi penyampaian dasar teori dan juga adanya praktik atau implementasi dari materi yang telah disampaikan. Dalam penyampaian materi pertama yaitu mengenai Fotografi, materi yang diberikan berkaitan dengan materi dasar fotografi meliputi pencahayaan, teknik penyesuaian angel, proporsi obyek, dan sebagainya. Penyampaian materi ini juga dilakukan dengan adanya praktik implemantasi dari materi yang dilakukan oleh peserta pelatihan dibantu oleh mentor yang hadir. Hasil dari pengerjaan praktik tersebut juga mendapatkan bentuk pengarahan dan evaluasi lanjutan oleh mentor.

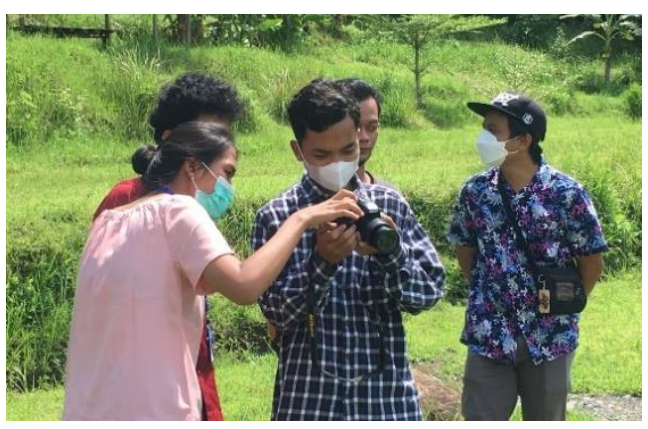

Gambar 2 Proses Pelatihan Fotografi

Pada mekanisme pelatihan teknik videografi disampaikan materi mengenai teknik dasar dalam pengambilan video. Dalam pembuatan konten video perlu adanya 3 tahapan yang dilewati yaitu pra- produksi, produksi, dan proses editing. Terdapat beberapa teknik dasar yang disampaikan dalam tiga alur proses tersebut, mulai dari pembuatan konsep dan story board, teknik pengambilan video, pencahayaan, pengenalan alat- alat, hingga pada video editing. Implementasi dari materi tersebut dibuat 4 kelompok untuk membuat video pendek di 4 kawasan berbeda yaitu Puncak Kleco, Sunga Tinalah, Museum Sandi, dan Goa Sriti. Hasil dari 4 video tersebut dipresentasikan pada akhir sesi pelatihan dan mendapatkan evaluasi lanjutan dari para mentor.

Materi yang disampaikan terkait tata cara berbicara atau public speaking untuk para penggiat desa wisata ketika melakukan guide pengunjung yang akan datang, para peserta diajak untuk sama-sama memahami cara berbicara dengan menarik, beramah tamah dengan para pengunjung seperti menyapa tamu dan lain sebagainya, juga cara berbasa-basi kepada pengunjung yang datang ketika akan menawarkan produk-produk yang ada di desa wisata, materi yang disampaikan juga mencakup: seni berbicara dalam pariwisata, public speaking dalam virtual tour, tata cara 
membuat tour yang interaktif, cara membuat desain interaksi yang menarik, pemberian informasi seputar guide yang baik seperti berpengetahuan yang luas dan memiliki rasa cinta terhadap tempat dia berada, dan lain sebagainya. Selain dari penyampaian materi tata cara public speaking yang baik dalam tour peserta juga diberi pemahaman terkait storynomic yang ada di dalam desa wisata, dimana peserta harus mengetahui pentingnya cerita-cerita yang ada di desa wisata yang harus tersampaikan kepada pengunjung ketika datang. Pada praktek materi yang dilakukan peserta ditunjuk satu persatu untuk mempraktekan materi, peserta juga melakukan role play atau permainan peran sebagai penggiat wisata yang akan kedatangan tamu atau pengunjung, dimana tim CBT dari Travelixsm berperan sebagai pengunjung yang datang dan para peserta sebagai guide yang menerima tamu. Tujuan dari praktek role play ini agar menjadi pelajaran dan pertimbangan ketika melakukan public speaking tour yang sebenarnya di waktu mendatang.

Materi hari ini membahas optimalisasi aplikasi yang dimiliki desa wisata Tinalah yang bernama Dewi Tinalah. Fokus optimalisasi hari ini adalah membahas games yang bisa dikembangkan melalui aplikasi tersebut dengan pemateri yakni mas Bima Murti. Mas Bima menjelaskan cara pengembangan games dengan teknik deep learning. Tim pengembangan games harus memfoto ratusan objek yang ada di sekitar desa wisata tinalah dan selanjutnya hasil foto tersebut di program oleh komputer agar dapat diidentifikasi oleh aplikasi. Tim pengembangan juga mewawancarai warga desa mengenai fungsi dan manfaat dari objek tersebut. Contoh pohon pisang, tim pengembangan memfoto ratusan pohon pisang yang ada di sekitar desa wisata Tinalah, selanjutnya tim juga mewawancarai warga terkait manfaat yang bisa didapat dari pohon pisang di desa tersebut seperti pembuatan pisang goreng dan sale pisang.

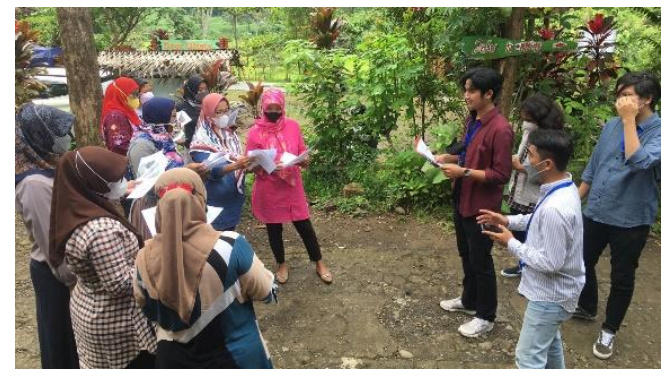

Gambar 3 Games untuk optimalisasi Aplikasi

Terdapat dua Games yang bisa dikembangkan melalui aplikasi yang pertama adalah games tebak gambar dan yang kedua adalah games mengidentifikasi wajah peserta. Teknis permainan game yang kedua yakni nantinya panitia game akan memberikan instruksi untuk mencari peserta lain yang memiliki aura wajah seperti objek yang diinstruksikan panitia. Contoh panitia menginstruksikan untuk mencari peserta yang memiliki aura wajah seperti objek batuan hitam dan stalakmit, maka peserta games harus mencari peserta lain yang memiliki aura wajah seperti objek tersebut dengan cara identifikasi wajah melalui aplikasi.
Setelah sesi penjelasan dari mas Bima, selanjutnya yakni sesi praktek bermain games.

Materi selanjutnya mengenai Cashless Society. Pemateri menjelaskan mengenai apa itu Cashless Society yang mana di pola masyarakat urban saat ini berkembang metode pembayaran transaksi tanpa adanya uang fisik. Upaya cashless yang berkembang saat ini dinilai sebagai bentuk kemudahan sarana konsumsi. Dengan mengunakan fitur pembayaran digital yang saat ini sudah tersedia platform QRIS(Quick Response Code Indonesian Standard) yang telah terintegrasi secara nasional dengan berbagai bank. Pengadaan QRIS ini meningkatkan potensi UMKM maupun produk wisata dalam menarik potensi transaksi atau pembelian karena menyediakan optional pembayaran yang fleksibel. Pada kegiatan praktek yang didampingi oleh 14 mentor yang hadir untuk membantu proses pendaftaran QRIS(Quick Response Code Indonesian Standard) oleh UMKM peserta yang hadir.

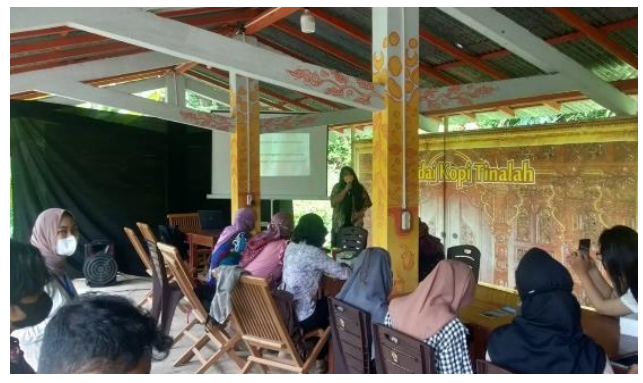

Gambar 4 Pelatihan Cashless Society

\section{KESIMPULAN}

Proses digitalisasi merupakan proses yang perlu melibatkan kontribusi masyarakat. Untuk meningkatkan ketrampilan diperlukan keterlibatan masyarakat dalam mencoba teknologi maupun menciptakan games interaktif. Dalam pengabdian masyarakat ini, tim telah menemukan beberapa manfaat dari digitalisasi wisata. Selain itu tim jugan menemukan kebutuhan lain yang bisa dilanjutkan untuk pengabdian masyarakat selanjutnya. Berikut adalah table pemetaan dari manfaat penagbdian masyarakat saat ini dan kebutuhan masyarakat untuk kebutuhan masyarakat selanjutnya.

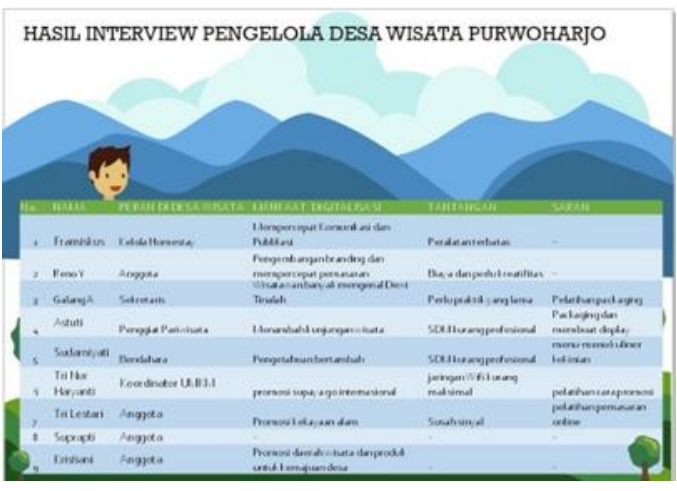

Gambar 5 Hasil Interview 


\section{UCAPAN TERIMAKASIH (HEADING 5)}

Atas publikasi ini penulis mengucapkan Terima kasih kepada ditjen dikti ristek atas bantuan pendanaan program penelitian Kebijakan Merdeka Belajar Kampus Merdeka dan Pengabdian kepada Masyarakat Berbasis Hasil Penelitian dan Purwarupa PTS Tahun Anggaran 2021.

\section{DAFTAR PUSTAKA}

[1] F. M. Grouzet and E. S. Lee, "Ecological Well-Being," in Encyclopedia of Quality of Life and Well-Being Research , Canada, Springer Refrance, 2014, pp. 17841787.

[2] J. K. Summers, L. M. Smith, J. L. Case and R. A. Linthurst, "A Review of the Elemnet of Human WellBeing with an Emphasis on the Contribution of Ecosystem Services," Ambio, p. 327-340, 2012.

L. Muliawanti and D. Susanti, "Digitalisasi Destinasi

[3] sebagai Strategi Pengembangan Promosi Pariwisata di Kabupaten Magelang," WARTA Ikatan Sarjana komunikasi Indonesia, pp. 135-143, 2020.

[4] B. P. W. Nirmala, N. W. utami and A. I. I. Paramitha, "Digitalisasi Desa dan Potensi Wisata di Desa Kerta, Kabupaten Gianyar Menuju Pariwisata 4.0," Jurnal Karya Abdi, pp. 350-355, 2020.

[5] T. A. S. P. O. a. C. S. Division, ASEAN Community Based Tourism Standard, Jakarta: Association of Southeast Asian Nations (ASEAN), 2016.

[6] É. Happ and Z. Ivancsó-Horváth, "Digital Tourism is the Challenge of Future- A New Approach to Tourism," Knowledge Horizons - Economics, pp. 9-16, 2018.

[7] V. Parida, "Digitalization," in Addressing Societal Challenges, Luleå, Grafisk produktion LTU, 2018, pp. 23-38.

[8] S. P. V. Lenka and J. Wincent, "Digitalization Capabilities as Enables of Value Co-Creation in servitizing Frims," Psysicology \& Marketing , pp. 92100, 2017.

[9] T. M. E. A. (MEA), Ecosystems and human well-being: Synthesis, Washington, DC: World Resources Institute, 2005.

\section{PENULIS}

Desideria Cempaka Wijaya
Murti, prodi Ilmu Komunikasi,
Fakultas Ilmu Sosial dan Ilmu Politik,
Universitas Atma Jaya Yogyakarta.

